\title{
Heavy Metals Occurrence, Seasonal Variation and Enrichment in Urban Soils Augmented with Industrial Waste
}

\author{
Muhammad Zubair ${ }^{1 *}$, Usama Anwar', Muhammad Ashfaq ${ }^{1}$, \\ Muhammad Nadeem Zafar', Mujahid Farid ${ }^{2}$, Fayyaz Ahmad ${ }^{3}$, Waqar Ahmad ${ }^{1}$, \\ Shafaqat Ali ${ }^{4 * 5 *}$, Muhammad Rizwan ${ }^{4}$, Abdulaziz Abdullah Alsahli ${ }^{6}$, \\ Mohammed Nasser Alyemeni ${ }^{6}$, Leonard Wijaya ${ }^{6}$ \\ ${ }^{1}$ Department of Chemistry, University of Gujrat, Gujrat 50700, Pakistan \\ ${ }^{2}$ Department of Environmental Sciences, University of Gujrat, Gujrat 50700, Pakistan \\ ${ }^{3}$ Department of Statistics, University of Gujrat, Gujrat 50700, Pakistan \\ ${ }^{4}$ Department of Environmental Sciences and Engineering, Government College University, 38000 Faisalabad, Pakistan \\ ${ }^{5}$ Department of Biological Sciences and Technology, China Medical University, Taichung 40402, Taiwan \\ ${ }^{6}$ Department of Botany and Microbiology, College of Science, King Saud University, 11451-Riyadh, Saudi Arabia
}

Received: 18 October 2020

Accepted: 10 January 2021

\begin{abstract}
Present study was planned on the basis of prior field survey with main objective to determine concentrations of selected metals temporally (winter, spring, summer) in the industrial waste sediments, accumulate and enrich in the soils of Gujranwala city. Initially, physiochemical properties of samples $\mathrm{pH}(>8)$ colour (grey to black), odour (phenolic) and textures (amorphous to granular) were studied. Moisture contents $0.15-31 \%$ with RSD 0.17-16.87 shows variation because of seasonal effect. Overall, ICP-OES analysis reveals concentrations of thirteen selected metals in the range $0.40-379200 \mathrm{mg} / \mathrm{kg}$ with lowest of $\mathrm{Ag}$ and highest of Al. Statistically, RMANOVA was applied to reveal significant variations within the metals and between the seasons, showing significant metals effect seasonally. Environmental risk was estimated using geo-accumulation index and enrichment factor comparing reference crustal values $(\mathrm{Bn})$ of metals in soil and $\mathrm{Fe}$ as reference metal. Aluminium accumulates very strongly and contaminate the soils more than Fe having no contamination in soil. Enrichment factor of Al also found highest indicating the highest enrichment level in the top soil. Overall, Fe and Al among thirteen elements found highest in quantity in the soil samples establishing significant impact in the soil due to their higher concentration. Finally, estimations are supporting the conclusion that metals may have a significant effect in soils where industrial waste is disposed.
\end{abstract}

Keywords: environment, waste, metals, contamination, seasonal

\footnotetext{
*e-mail: muhammad.zubair@uog.edu.pk
}

*e-mail: shafaqataligill@yahoo.com 


\section{Introduction}

Intense urbanization and industrialization result in the production of large waste in urban environments. Dumping of solid industrial waste is normally managed in landfills in developed countries, whereas in developing countries it is thrown away on open land places [1]. Several toxic metals release from the industrial waste have severe synergistic effects on the environment and health [2, 3]. Toxic metals not only affect biological life but also transmit biochemical changes in soil environments and plants. Heavy metals concentration effect the enzymatic action of soil biota, which largely influence the microbial life and reduce the soil microorganism [4]. The concentration of the heavy metals is increasing in the environment due to various anthropogenic activities [5]. Poor waste management adversely affects the urban environment and human health of community living there, which is more evident in developing countries having rapid population growth and less resources [6]. Major sources of heavy metals accumulation and enrichment in urban soils are industries disposing waste along weathered materials generates through various anthropogenic actions [7]. Major industrial processes that are responsible for contributing to the concentration of heavy metals, include foundries, smelters, piping, combustion of raw waste material, and mining activities [8]. Gujranwala, the fourth most populated city of Pakistan, is located $32.16,74.02$ north east from the equator and $60 \mathrm{~km}$ towards north of Lahore, the capital city of the province of Punjab. It has well customary industrial operations for the production of variety of locally and globally needed household items, sanitary wares, fan wings and electric motors, electric wires, and windings. During the production of these useful articles, a substantial amount of metal concentrated waste is produced. Mostly these industries do not follow criteria and legal protocols for disposing waste comprising heavy toxic metals on open places in city areas [9]. This malpractice is resulting in significant increase in metallic waste and then contamination of urban soils and groundwater. Despite the unlawful discharge of a large amount of metal-enriched industrial waste, the level of heavy metals in the waste of this urban area has not been previously determined. Therefore, it is a matter of prime importance to determine the concentration of metals and their risk the larger population. According to the 2017 census, the total population of the Gujranwala division is 5.01 million, 2.06 million of which is urban and 2.9 million of which is rural. This mismanaged increase of industrial waste has become an environmental problem for administrative waste management policy makers, due to the lack of municipal amenities. The population of developing countries is another factor that adversely affects the environmental because the increasing population, damages the environment by using natural resources and creating pollution. In a situation like Pakistan's, urban population grows with the highest proportion, about $40 \%$ faster than South Asian countries [10]. Unlike the common solid waste of Asian cities, up to $80 \%$ of which is composed of organic matter [11] the industrial waste chosen for the present research study is comprising heavy metals of different toxic potential. Uncontrolled toxic wastes from industries after mixing with municipal wastes create potential risks to human health. Specifically, the heavy metals present in the bulk enters the environment and food chain [12]. Taking into account the dumping of industrial waste on urban soils bearing heavy metals, the present study was planned to (1) assess the occurrence and seasonal variation of selected elements (Fe, Al, Mn, $\mathrm{Cu}, \mathrm{Zn}, \mathrm{Ba}, \mathrm{B}, \mathrm{Cr}, \mathrm{Pb}, \mathrm{Ni}, \mathrm{Cd}, \mathrm{Ag}$, and $\mathrm{Tl}$ ) in samples of industrial waste dumped on soils in Gujranwala, Pakistan, and (2) evaluate the environmental pollution risk of analyzed metals. This is one of the key study planned for the metals concentrations, and their risk assessment in urban soil of Gujranwala polluted with metal industrial waste. The results of study will be helpful for generating baseline data for future policy making and planning by the administrative framework.

\section{Material and Methods}

\section{Chemicals and Reagents}

All the reagents used in research work were of high purity analytical grade, purchased from Merck, Sigma Aldrich and BDH, without any further purification. Pyrex glassware such as beakers, volumetric flasks, and measuring cylinders were used for conducting experimental work in the laboratory. Deionized water was obtained from Ittehad Chemical Industries, Lahore, Pakistan, for preparing solutions. Material decontamination procedures were followed. Glassware was thoroughly washed with detergents and aqua regia to remove all contaminants. The sampling material contains toxic elements, so all safety measures regarding personal protective equipment were taken. Used materials were disposed off according to standard procedures.

\section{Sampling}

Gujranwala is one of the most populated cities and is located 32.16, 74.02 north east with respect to the equator. A systematic composite sampling strategy (triplicate) was adopted from 15 different locations (Fig. 1) in three different seasons of the year on November 2016 (Season 1, winter), March 2017 (Season 2, spring), and July 2017 (Season 3, summer). The details of the sampling points can be found in Table S1 of the supplemental information (SI). Sampling sites were divided into five zones of Gujranwala with major industrial activities: Sanat Zar Road, Kousar Fan Street, Sialkot Road, Alam Chowk, and Canal Road, as shown in the GIS map in Fig. 1. Geospatial sampling 


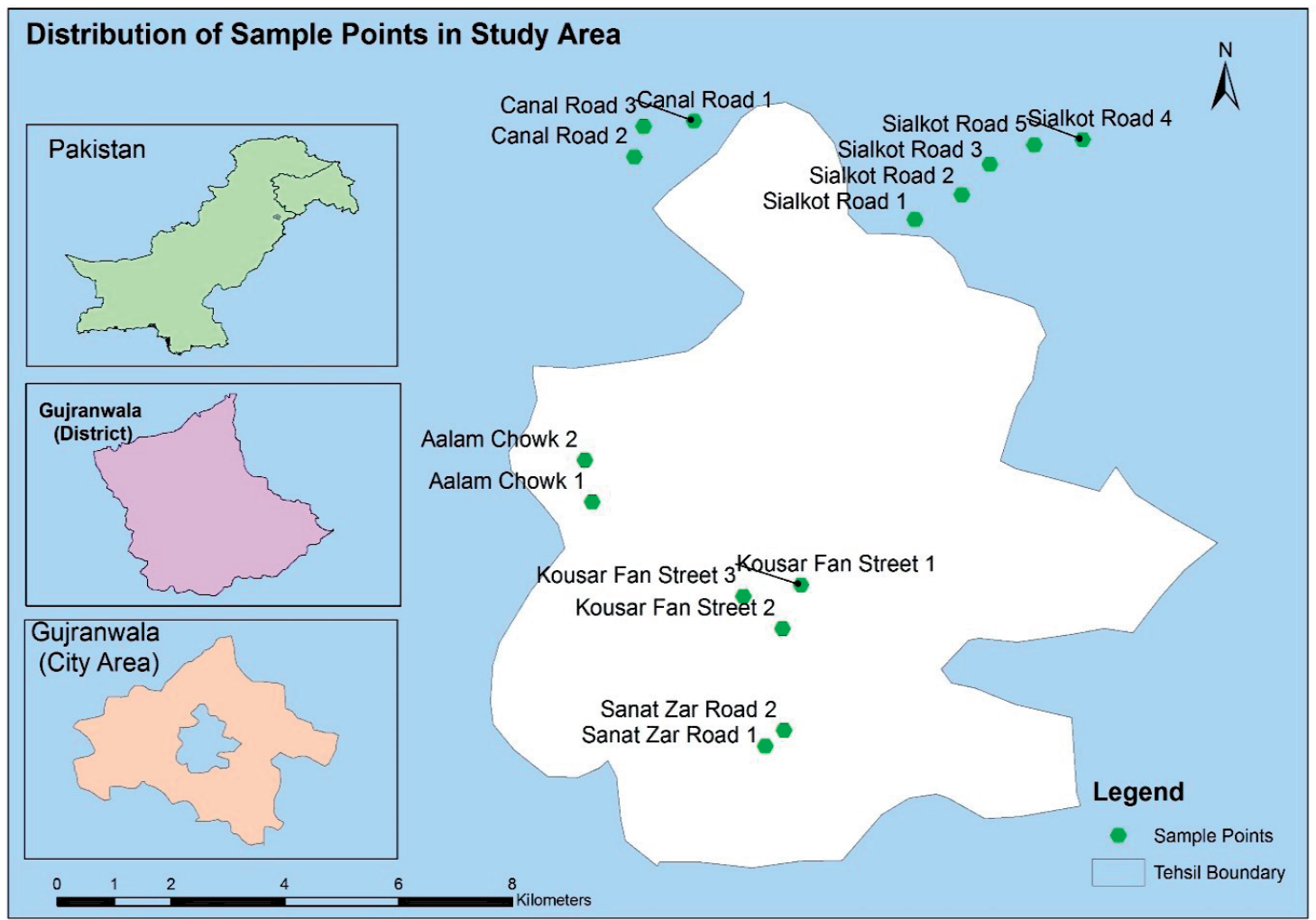

Fig. 1. Sampling points $(n=15)$ of potential sites of industrial waste of Gujranwala city.

was performed from an upper layer up to a $40 \mathrm{~cm}$ depth of the dumping area. Samples were taken into clean, irradiated aseptic plastic falcon tubes of $150 \mathrm{~g}$ to avoid any kind of contamination. After collection, samples were preserved under cold conditions $\left(<4^{\circ} \mathrm{C}\right)$ to avoid any kind of chemical and physical change, until sample preparation and analysis. The moisture content and $\mathrm{pH}$ of the waste were measured using standard protocols and are found in Table S2.

\section{Sample Preparation and ICP-OES Analysis}

A weighed quantity $(2.0 \mathrm{~g})$ of each dried sample of sediments was digested in a digestion flask using $5.0 \mathrm{~mL}$ concentrated nitric acid ( $\mathrm{HNO} 3)$. The mixture was heated on a hot plate at about $80^{\circ} \mathrm{C}$ for $2-3 \mathrm{~h}$. After cooling, $3.0 \mathrm{~mL}$ of hydrogen peroxide $\left(\mathrm{H}_{2} \mathrm{O}_{2}\right)$ was added into the digested mixture and heated again at $160-170^{\circ} \mathrm{C}$ to oxidize carbon contents. After filtration of digested material was diluted to $25 \mathrm{~mL}$ adding deionized water. Samples were then analyzed using a simultaneous inductively coupled plasma optical emission spectrophotometer (ICP-OES) model (Thermo Scientific iCAP 7000 Series), employing conditions of a flush pump rate $35 \mathrm{rpm}$, an analysis pump rate of $20 \mathrm{rpm}$, a stability time of $20 \mathrm{sec}$, an RF of $1250 \mathrm{KV}$, an auxiliary gas flow of $1.0 \mathrm{~L} / \mathrm{min}$, a nebulizer flow of $0.65 \mathrm{~L} / \mathrm{min}$, and a coolant gas flow of $15 \mathrm{~L} / \mathrm{min}$, with a radial view height of $8.0 \mathrm{~mm}$. The detection limit of the method was $0.001 \mathrm{ppm}$. A standard solution of multielement concentration (1000 ppm) was used, purchased from Accu standards. Calibration was performed using five different concentrations: 10, 20, 30, 40, and $50 \mathrm{ppm}$.

\section{Geo Accumulation Index}

The geo accumulation index of metals in soil was calculated following a reported method $[13,14]$ :

$$
\text { Igeo }=\log _{2}(\mathrm{Cn} / 1.5 \mathrm{Bn})
$$

...where

$\mathrm{Cn}=$ Measured concentration of the metal in the sample, $\mathrm{Bn}=$ Geochemical background value in the Earth's crust (Table S4) [15].

The factor 1.5 introduced in Equation (1) to minimize the effect of possible lithogenic variations in the background metal concentration.

\section{Enrichment Factor}

The enrichment factor of the investigated metals was calculated according to the following equation as also used previously [16]:

$$
\mathrm{EF}=\mathrm{Mx} \times \mathrm{Feb} / \mathrm{Mb} \times \mathrm{Fex}
$$

...where Mx and Fex represent the concentrations of a particular metal and iron in the sediment sample, while $\mathrm{Mb}$ and Feb represent background concentrations of a particular metal and iron, respectively [17]. In common practice, to calculate the metal enrichment in soil, 


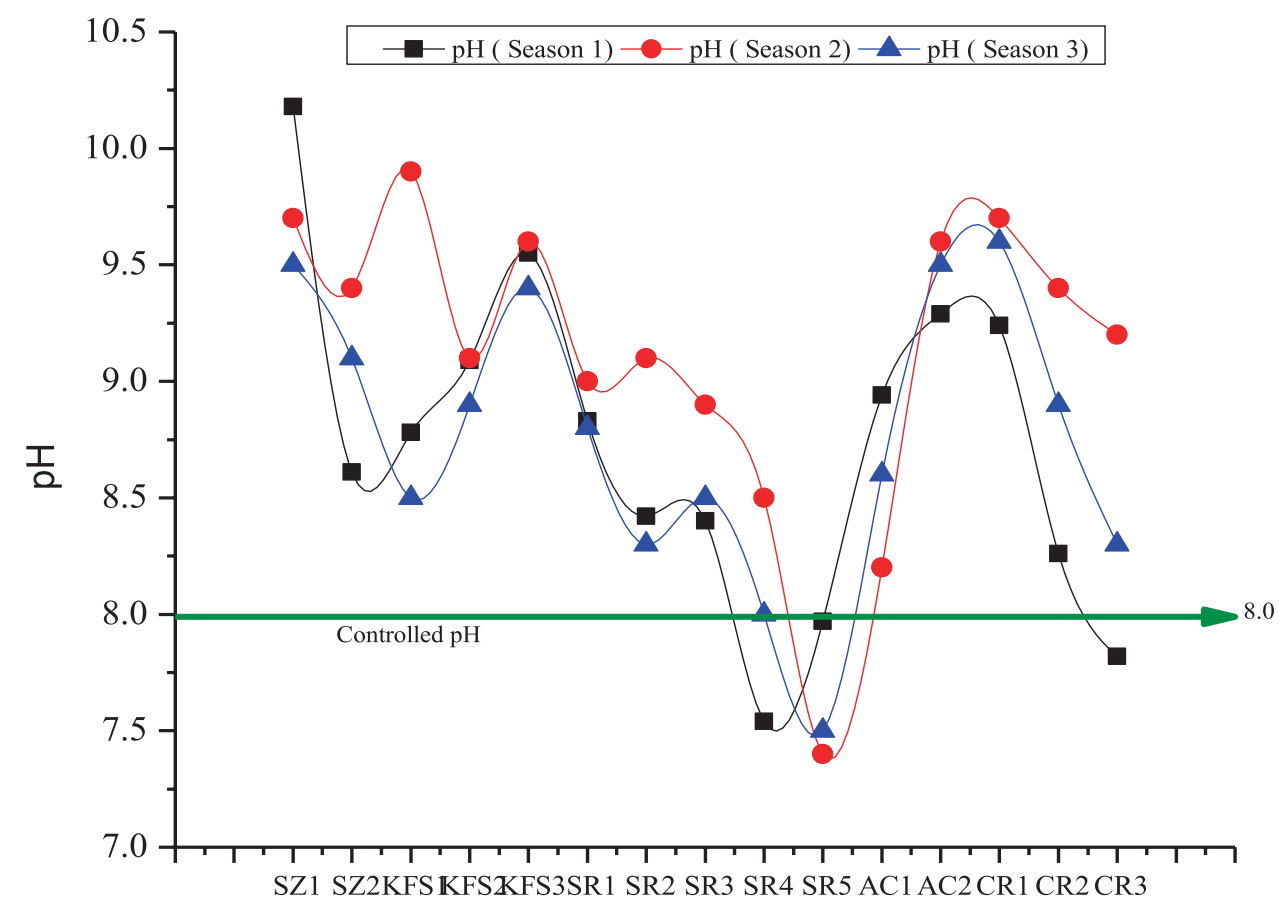

Samples

Fig. 2. Variation in $\mathrm{pH}$ of $\mathrm{n}=15$ samples of $\mathrm{n}=3$ seasons in comparison to control soil $\mathrm{pH}$.

the concentration of reference metals, preferably $\mathrm{Fe}$ or $\mathrm{Al}$, is used [18-20]. In the present study, the enrichment factor was estimated for metals by taking $\mathrm{Fe}$ as a reference metal because $\mathrm{Fe}$ has the least toxicity relative to its occurrence in sediments.

\section{Statistical Analysis}

Statistical data are reported as ranges and means $(\mathrm{n}=3 \times 3)$. RMANOVA was applied to reveal significant variations within the metals and between the seasons, showing significant metals effect seasonally. Seasonal variation in metal concentrations is evaluated using the LSD test.

\section{Results and Discussion}

\section{Physiochemical Parameters}

For the present study, 15 composite samples were picked from critical points (Fig. 1) to assess the soil pollution of heavy metals present in industrial waste. Of the samples, physical parameters such as color, texture, moisture, and $\mathrm{pH}$ were determined and are presented in Tables S1 and S2 and Fig. 2. A notable variation in sample color from grey to black was present, which supports the results of metals analysis showing a major aluminium concentration [21]. Grey was also an indication of the abundance of aluminum, whereas black indicates the oxidation of metals and complexation with organic matter under suitable environmental conditions such as salinity and $\mathrm{pH}$. Apparent variations in the particle size of different samples as presented in Table S1 clearly range from amorphous to granular. In the preliminary examination for moisture and solid mass contents, there was significant variation depicting a maximum relative standard deviation (RSD) of $16.87 \%$ in the sample SR1 and a minimum of $0.17 \%$ in KFS2 (Table S2). Variation in the moisture may be due to the difference in climatic conditions of dry and wet seasons as well as the nature of the disposed waste. The $\mathrm{pH}$ of the samples was investigated to identify the chemical nature of the different samples of soil sediments. All the samples were found to be basic in nature with mean values of $8.72,9.11$, and 8.76 in all three seasons, respectively (Fig. 2); however, no statistically significant seasonal variability in $\mathrm{pH}$ is apparent. Results from RMANOVA showed significant effect of season, location and their interaction on the soil $\mathrm{pH}$ similarly, in another research study it a level of $\mathrm{pH}$ greater than 7.0 in domestic landfills comprising organic waste is reported [22]. The basic $\mathrm{pH}$ found in our samples representing the formation basic oxides and hydroxides of metals present in metallic waste. The toxicity and mobility of heavy metals depends preferably on their chemical natures and sole distribution of their total concentrations in soil sediments; however, it is not sufficient to recognize the severity of the environmental damage caused by them $[23,24]$. Soil $\mathrm{pH}$ influenced the heavy metal adsorption and mobility. Several studies have revealed that soil characteristics are linked to the adsorption and mobility of heavy metals; a $\mathrm{pH}$ increase brought an increase in the metal adsorption 


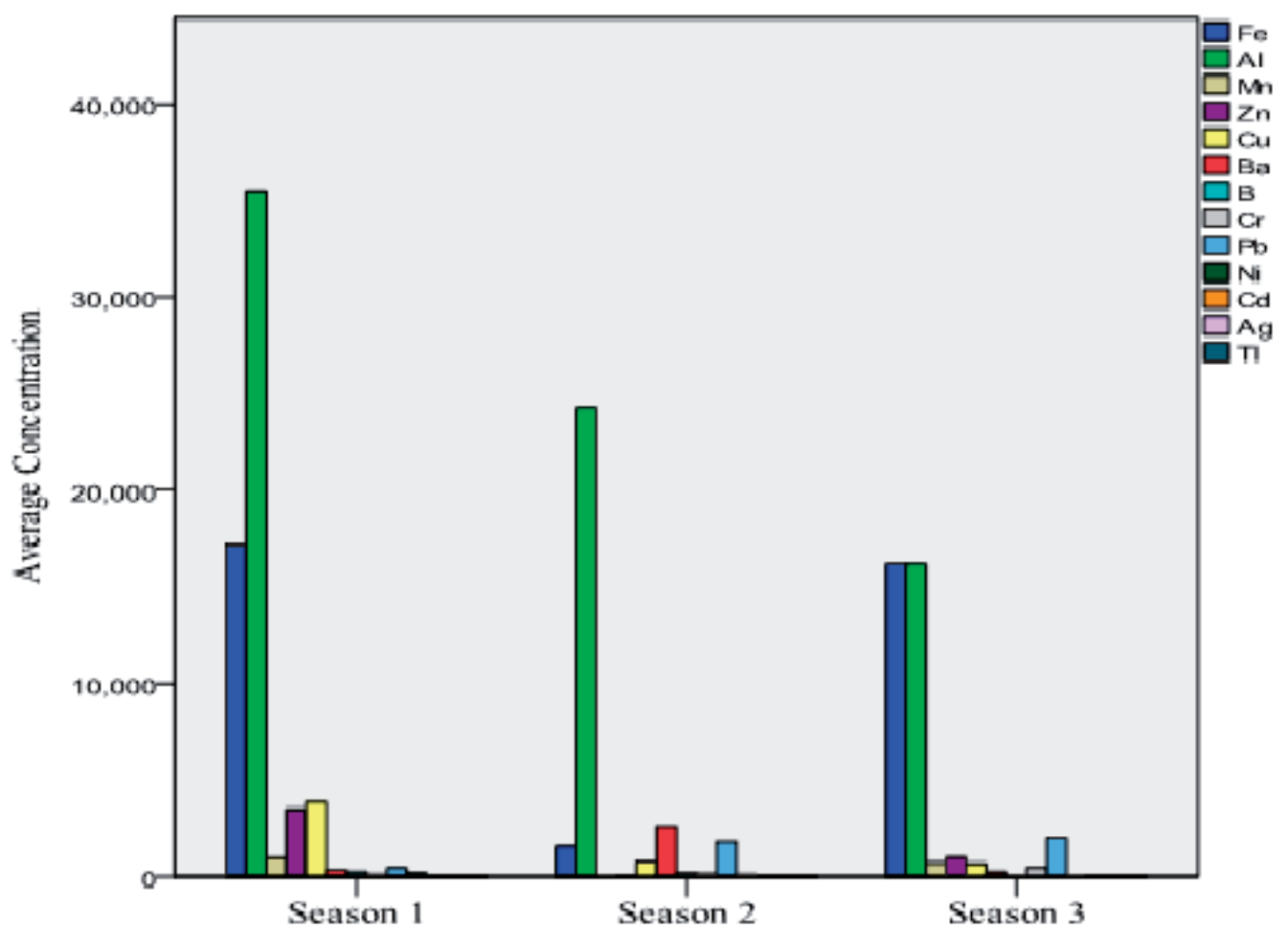

Fig. 3. Average concentration of metals corresponding to three seasons.

and influenced heavy metal precipitation. It is evident from the from the numerous literature data, that the increase in $\mathrm{pH}$ up to 10 results in a significant decrease in the concentration of zinc in plants. However, there is a general consideration that low soil $\mathrm{pH}$ prompts a high metal mobility [25]. As shown by the graphical representation, the $\mathrm{pH}$ of our samples mostly lies in and above the safety range of 8.0 , which indicates that the mobility of the soil's heavy metals is retarded, which may lead to a greater accumulation and hence become toxic. With a low acidic $\mathrm{pH}(<5)$, the oxides of $\mathrm{Al}$ and $\mathrm{Fe}$ are depleted because of the resulting release of metals into the soluble phase. When metal waste is left at the soil's top layer, then the oxidation of sulfides may generate a low acidic $\mathrm{pH}$, which provokes increasing solubility for heavy metals [26]. Our research results showed high concentrations of $\mathrm{Al}$ and $\mathrm{Fe}$ among limited amounts of other transition heavy metals. In addition, the $\mathrm{pH}$ values of the sediment soil samples also have a higher $\mathrm{pH}$ of more than 8.0, which supports the retardation of metal mobility and solubility. From the retardation aspect, it may be concluded that more concentrations of heavy metals could be toxic to life and the environment.

\section{Elemental Analysis}

Thirteen metals (Al, Fe, Cu, Zn, Mn, Pb, Ba, B, Ni, $\mathrm{Cr}, \mathrm{Cd}, \mathrm{Ag}$, and $\mathrm{Tl}$ ) reported in the literature as toxic and have their effects, were chosen for analysis using ICP-OES. After experiencing working of industries, it was found that metals are extensively used in domestic housewares. Waste of these industries is dumped on open land available as indicated sampling points on map. Table S3 showing the range $\mathrm{mg} / \mathrm{kg}$ (Min-Max) of three seasons (spring, summer, winter) and Fig. 3 showing the average concentration of metals in each season. Aluminium (Al) is highest in concentration found $379,200 \mathrm{mg} / \mathrm{kg}$ in season one and more than $35000 \mathrm{mg} / \mathrm{kg}$ average of three seasons. High concentration of aluminium represents its leading use in industrial metal wares, various kinds of domestic items and commercial articles such as electrical fans and motorcycle parts. Following aluminium, iron (Fe) is second most abundant metal, with a concentration $45,000 \mathrm{mg} / \mathrm{kg}$ of highest in season-3 and an average concentration $18415 \mathrm{mg} / \mathrm{kg}$. Evaluation of the metal concentrations in the samples of three different seasons has revealed a significant seasonal variability in the concentration of major elements (Fig. 4). Fig. 5 presents a comparison of the determined average concentrations of metals in the samples of three seasons, with reference threshold concentration in soils obtained from the literature. Green points on the vertical lines representing a safe level of metal that is not harmful to the environment, whereas other indicators represent the metal concentrations of seasons. The line connecting the green points is not a trend line, but represents the control line for the metals. The values of metals on the y-axis are represented in $\log 10$ to control the large difference of values in the graphical presentation. It can be clearly seen in the figure that the $\mathrm{Fe}, \mathrm{Mn}$, and $\mathrm{Ag}$ values are in a safe limit, whereas other metals have higher concentrations of metals in soil samples. 


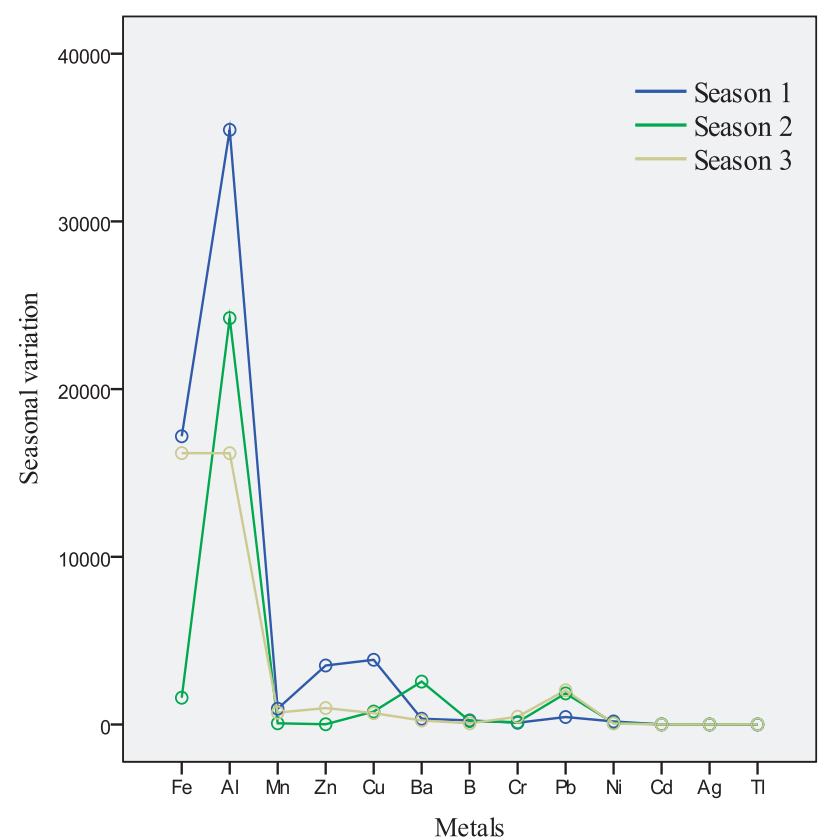

Fig. 4. Seasonal variation of metals in $n=15$ sample analyzed with ICP-OES.

Greater concentrations of metals over the safer limit may affect the soil environment through accumulation, adsorption, and enrichment. Enrichment of metals in the soil may lead to toxic implications. Control background values or crustal values 1 to $35,000 \mathrm{mg} / \mathrm{kg}$ on average of metals used for comparison with determined were taken from literature which are considered as reference metal concentration in different research studies from [27-31]. These values have reciprocating effects and important to discuss that the lowest value of reference metal means that it has a higher contamination than highest concentration in the soil. As per the reported values, Tl has the highest potential of contamination, with only $1.0 \mathrm{mg} / \mathrm{kg}$, whereas Fe has the least potential, with a value of $35,000 \mathrm{mg} / \mathrm{kg}$. Fe has no contamination in the soil, whereas $\mathrm{Ag}, \mathrm{Pb}$, and $\mathrm{Cd}$ have a potential for contamination even with lower concentrations (Table S3). Aluminium concentrations are high in the samples, indicating a source of food and medicine packing material from where aluminium is extracted. A similar research study was conducted on effect of seasonal flooding on elemental contents of $\mathrm{Al}, \mathrm{Cd}$, $\mathrm{Cr}, \mathrm{Ni}, \mathrm{Cu}, \mathrm{As}, \mathrm{Pb}$ and $\mathrm{Zn}$ in a Chinese delta. The results of concentration of $\mathrm{Al}(33,774.12 \mathrm{mg} / \mathrm{kg})$ and Cr $(84 \mathrm{mg} / \mathrm{kg})$, were in support of our results [21]. The mean concentrations of aluminium were $35,459.12 \mathrm{mg} / \mathrm{kg}, 24,232.4 \mathrm{mg} / \mathrm{kg}$, and $16,177.43 \mathrm{mg} / \mathrm{kg}$ during Season 1, Season 2, and Season 3 respectively. The threshold value of aluminium was $10 \mathrm{mg} / \mathrm{kg}$, whereas the average measured concentrations of $\mathrm{Al}$ in all seasons were above the toxic range. In statistical analysis repeated measures MANOVA was calculated to predict the significant variations among the metals in different seasons (Table 1). SPSS analysis prints out partial eta-squared as an effect size index (partial etasquared: $.01=$ small, $.06=$ medium, $.14=$ large $)$. Based on index values as shown Table 1, the effect size (partial eta-squared $=.749$ ) was large in our heavy metals dataset. Moreover, we analyzed the effect of seasons on the set of dependent variables (Fe, $\mathrm{Al}, \mathrm{Mn}, \mathrm{Zn}, \mathrm{Cu}, \mathrm{Ba}$, $\mathrm{B}, \mathrm{Cr}, \mathrm{Pb}, \mathrm{Ni}, \mathrm{Cd}, \mathrm{Ag}, \mathrm{Tl}$ ) was statistically significant, Wilks' lambda $=.749, \mathrm{~F}(39,96)=7.024, \mathrm{p}<0.001$. A one-way repeated measures multivariate analysis of variance (RMANOVA) was used to determine whether there are any differences in selected metal concentrations (Fe, Al, Mn, Zn, Cu, Ba, B, Cr, Pb, Ni, Cd, Ag, Tl) over three seasons (Table 2). The estimated parameters and

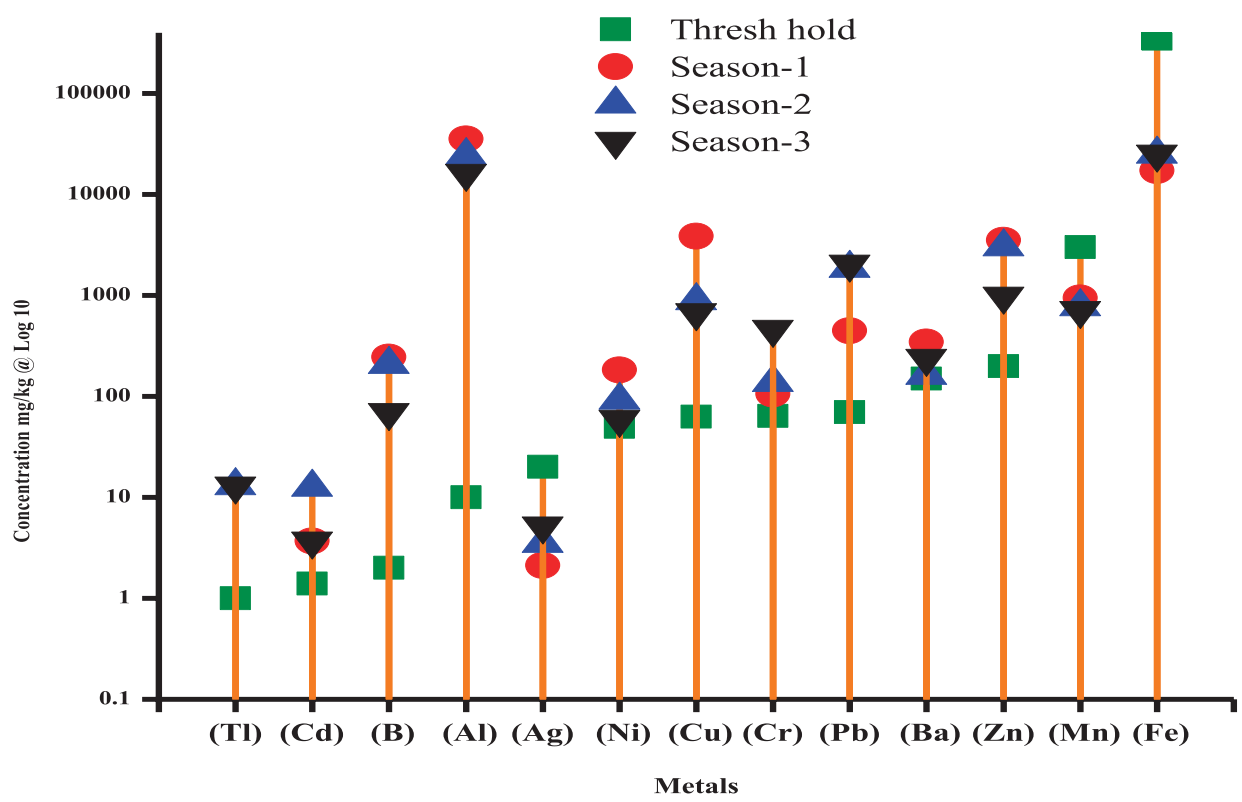

Fig. 5. Seasonal metals concentrations ( $\mathrm{mg} / \mathrm{kg}$ of $\log 10)$ vs. reference threshold values. 
Table 1. Repeated measures MANOVA to identify significant seasonal variation.

\begin{tabular}{|c|c|c|c|c|c|c|c|}
\hline \multicolumn{2}{|c|}{ Effect } & Value & F & Hypothesis df & Error df & Sig. & Partial Eta Squared \\
\hline \multirow{4}{*}{ Season } & Pillai's Trace & 1.972 & 4.722 & 39 & 96 & .000 & .657 \\
\cline { 2 - 8 } & Wilks' Lambda & .016 & 7.024 & 39 & 89 & .000 & .749 \\
\cline { 2 - 8 } & Hotelling's Trace & 14.160 & 10.408 & 39 & 86 & .000 & .825 \\
\cline { 2 - 8 } & Roy's Largest Root & 11.284 & $27.776^{\mathrm{b}}$ & 13 & 32 & .000 & .919 \\
\hline
\end{tabular}

a. Design: Season

b. The statistic is an upper bound on $\mathrm{F}$ that yields a lower bound on the significance level.

effect sizes (Partial Eta Squared) exist small or large over seasons. For example, Fe has large effect $(0.456)$ over season 1 and no effect (0.007) over season 2 . Table 1 RMANOVA estimation reveals that there is not on average a significant variability in the concentration of metals. There is no seasonal effect on the metals it may be discussed that metals are not decomposed or distribute with in sediment environment however they are constantly depositing in the waste disposed from the industries. Table 2 RMANOVA indicated interesting fact of metals effect with respect to each season. Metals has significant effect in three seasons. Large quantities and limited information about, metallic waste has made it an environmental challenge. A study was conducted in Xiamen, China, on the occurrence and variations of 52 metals, and the concentrations of commonly used industrial metals were in the range of $125-53,500 \mathrm{mg} / \mathrm{kg}$, which are close to our results of waste metals analysis of 15 different metals [32]. In another study of metal concentration from drilling waste discharges in Khyber Pakhtunkhwa, Ba, Zn, Ni, $\mathrm{Mn}, \mathrm{Cr}, \mathrm{Cd}$, and $\mathrm{Pb}$ concentrations analysed by Atomic

Table 2. Repeated measures (RMONOVA) for parameter (Metals \& Seasons) estimates.

\begin{tabular}{|c|c|c|c|c|c|c|c|c|}
\hline \multirow{2}{*}{$\begin{array}{l}\text { Dependent } \\
\text { Variable }\end{array}$} & \multirow{2}{*}{ Parameter } & \multirow{2}{*}{ B } & \multirow{2}{*}{ Std. Error } & \multirow{2}{*}{$\mathrm{t}$} & \multirow{2}{*}{ Sig. } & \multicolumn{2}{|c|}{ 95\% Confidence Interval } & \multirow{2}{*}{$\begin{array}{c}\text { Partial Eta } \\
\text { Squared }\end{array}$} \\
\hline & & & & & & Lower Bound & Upper Bound & \\
\hline \multirow{3}{*}{$\mathrm{Fe}$} & {$[$ Season $=1]$} & 17187.347 & 2894.783 & 5.937 & 0.000 & 11345.439 & 23029.255 & 0.456 \\
\hline & {$[$ Season $=2]$} & 1597.767 & 2894.783 & 0.552 & 0.584 & -4244.141 & 7439.675 & 0.007 \\
\hline & {$[$ Season $=3]$} & 16183.207 & 2894.783 & 5.590 & 0.000 & 10341.299 & 22025.115 & 0.427 \\
\hline \multirow{3}{*}{$\mathrm{Al}$} & {$[$ Season $=1]$} & 35459.120 & 16603.628 & 2.136 & 0.039 & 1951.643 & 68966.597 & 0.098 \\
\hline & {$[$ Season $=2]$} & 24232.480 & 16603.628 & 1.459 & 0.152 & -9274.997 & 57739.957 & 0.048 \\
\hline & {$[$ Season $=3]$} & 16177.440 & 16603.628 & 0.974 & 0.335 & -17330.037 & 49684.917 & 0.022 \\
\hline \multirow{3}{*}{$\mathrm{Mn}$} & {$[$ Season $=1]$} & 941.873 & 250.681 & 3.757 & 0.001 & 435.979 & 1447.767 & 0.252 \\
\hline & {$[$ Season $=2]$} & 72.153 & 250.681 & 0.288 & 0.775 & -433.741 & 578.047 & 0.002 \\
\hline & {$[$ Season $=3]$} & 708.273 & 250.681 & 2.825 & 0.007 & 202.379 & 1214.167 & 0.160 \\
\hline \multirow{3}{*}{$\mathrm{Zn}$} & {$[$ Season $=1]$} & 3518.493 & 743.722 & 4.731 & 0.000 & 2017.602 & 5019.385 & 0.348 \\
\hline & {$[$ Season $=2]$} & 15.540 & 743.722 & 0.021 & 0.983 & -1485.351 & 1516.431 & 0.000 \\
\hline & {$[$ Season $=3]$} & 981.087 & 743.722 & 1.319 & 0.194 & -519.805 & 2481.978 & 0.040 \\
\hline \multirow{3}{*}{$\mathrm{Cu}$} & {$[$ Season $=1]$} & 3858.573 & 1188.119 & 3.248 & 0.002 & 1460.853 & 6256.294 & 0.201 \\
\hline & {$[$ Season $=2]$} & 773.413 & 1188.119 & 0.651 & 0.519 & -1624.307 & 3171.134 & 0.010 \\
\hline & {$[$ Season $=3]$} & 677.820 & 1188.119 & 0.570 & 0.571 & -1719.900 & 3075.540 & 0.008 \\
\hline \multirow{3}{*}{$\mathrm{Ba}$} & {$[$ Season $=1]$} & 344.707 & 557.979 & 0.618 & 0.540 & -781.341 & 1470.755 & 0.009 \\
\hline & {$[$ Season $=2]$} & 2559.453 & 557.979 & 4.587 & 0.000 & 1433.405 & 3685.501 & 0.334 \\
\hline & {$[$ Season $=3]$} & 239.747 & 557.979 & 0.430 & 0.670 & -886.301 & 1365.795 & 0.004 \\
\hline \multirow{3}{*}{ B } & {$[$ Season $=1]$} & 244.280 & 107.050 & 2.282 & 0.028 & 28.244 & 460.316 & 0.110 \\
\hline & {$[$ Season $=2]$} & 208.913 & 107.050 & 1.952 & 0.058 & -7.123 & 424.950 & 0.083 \\
\hline & {$[$ Season $=3]$} & 69.040 & 107.050 & 0.645 & 0.522 & -146.996 & 285.076 & 0.010 \\
\hline \multirow{3}{*}{$\mathrm{Cr}$} & {$[$ Season $=1]$} & 105.807 & 230.020 & 0.460 & 0.648 & -358.392 & 570.005 & 0.005 \\
\hline & {$[$ Season $=2]$} & 138.293 & 230.020 & 0.601 & 0.551 & -325.905 & 602.492 & 0.009 \\
\hline & {$[$ Season $=3]$} & 464.280 & 230.020 & 2.018 & 0.050 & .081 & 928.479 & 0.088 \\
\hline
\end{tabular}


Table 2. Contunued.

\begin{tabular}{|c|c|c|c|c|c|c|c|c|}
\hline \multirow{3}{*}{$\mathrm{Pb}$} & {$[$ Season $=1]$} & 446.187 & 903.162 & 0.494 & 0.624 & -1376.468 & 2268.842 & 0.006 \\
\hline & {$[$ Season $=2]$} & 1855.160 & 903.162 & 2.054 & 0.046 & 32.505 & 3677.815 & 0.091 \\
\hline & {$[$ Season $=3]$} & 2044.107 & 903.162 & 2.263 & 0.029 & 221.452 & 3866.762 & 0.109 \\
\hline \multirow{3}{*}{$\mathrm{Ni}$} & {$[$ Season $=1]$} & 182.487 & 64.454 & 2.831 & 0.007 & 52.412 & 312.561 & 0.160 \\
\hline & {$[$ Season $=2]$} & 91.867 & 64.454 & 1.425 & 0.161 & -38.208 & 221.941 & 0.046 \\
\hline & {$[$ Season $=3]$} & 59.400 & 64.454 & 0.922 & 0.362 & -70.674 & 189.474 & 0.020 \\
\hline \multirow{3}{*}{$\mathrm{Cd}$} & {$[$ Season $=1]$} & 3.707 & 2.108 & 1.758 & 0.086 & -.548 & 7.962 & 0.069 \\
\hline & {$[$ Season $=2]$} & 12.640 & 2.108 & 5.995 & 0.000 & 8.385 & 16.895 & 0.461 \\
\hline & {$[$ Season $=3]$} & 3.700 & 2.108 & 1.755 & 0.087 & -.555 & 7.955 & 0.068 \\
\hline \multirow{3}{*}{$\mathrm{Ag}$} & {$[$ Season $=1]$} & 2.127 & 0.664 & 3.204 & 0.003 & 0.787 & 3.466 & 0.196 \\
\hline & {$[$ Season $=2]$} & 3.546 & 0.664 & 5.342 & 0.000 & 2.206 & 4.886 & 0.405 \\
\hline & {$[$ Season $=3]$} & 5.073 & 0.664 & 7.642 & 0.000 & 3.734 & 6.413 & 0.582 \\
\hline \multirow{3}{*}{ TI } & {$[$ Season $=1]$} & 0.000 & 1.140 & 0.000 & 1.000 & -2.300 & 2.300 & 0.000 \\
\hline & {$[$ Season $=2]$} & 13.067 & 1.140 & 11.465 & 0.000 & 10.767 & 15.367 & 0.758 \\
\hline & {$[$ Season $=3]$} & 12.979 & 1.140 & 11.388 & 0.000 & 10.679 & 15.279 & 0.755 \\
\hline
\end{tabular}

Absorption Spectrometric methods, have close metal concentrations as in our study, so soil contamination potential may be equal. High concentrations of heavy metals, especially $\mathrm{Pb}$ and $\mathrm{Ba}$, were also detected in the surrounding soil samples [33]. Our research is relevant to another study on the metal $(\mathrm{Pb}, \mathrm{Ni}, \mathrm{Fe}, \mathrm{Zn}, \mathrm{Cd}$, and $\mathrm{Cu}$ ) concentrations in water, soil and waste after sludge and floatation at Kishnica mines in Kosovo. Regarding the concentration of these heavy metals, it was presented that the order of growth of such chemical elements was $\mathrm{Pb}>\mathrm{Cu}>\mathrm{Fe}>\mathrm{Cd}>\mathrm{Ni}$ and $\mathrm{Zn}[34,35]$. The specific hazards associated with these metals $(\mathrm{Pb}, \mathrm{Ni}$, $\mathrm{Fe}, \mathrm{Zn}, \mathrm{Cd}$, and $\mathrm{Cu}$ ) in the environment are not the only pollution but also their persistence in nature and bioaccumulation through food chain [36]. A study was conducted in Kaduna state, Nigeria, on heavy metal content and physicochemical properties of soils from solid waste dumpsites and concentrations of 7 different heavy metals were in the range of $19.0-5741.0 \mathrm{mg} / \mathrm{kg}$, which are in close agreement with our results of analysis of 15 different metals [37].

\section{Geo Accumulation Index}

The geo-accumulation index was calculated using the measured concentration $(\mathrm{Cn})$ of the metal in the samples and the geochemical background (Bn) value in the earth's crust, as presented in Table S4. Results

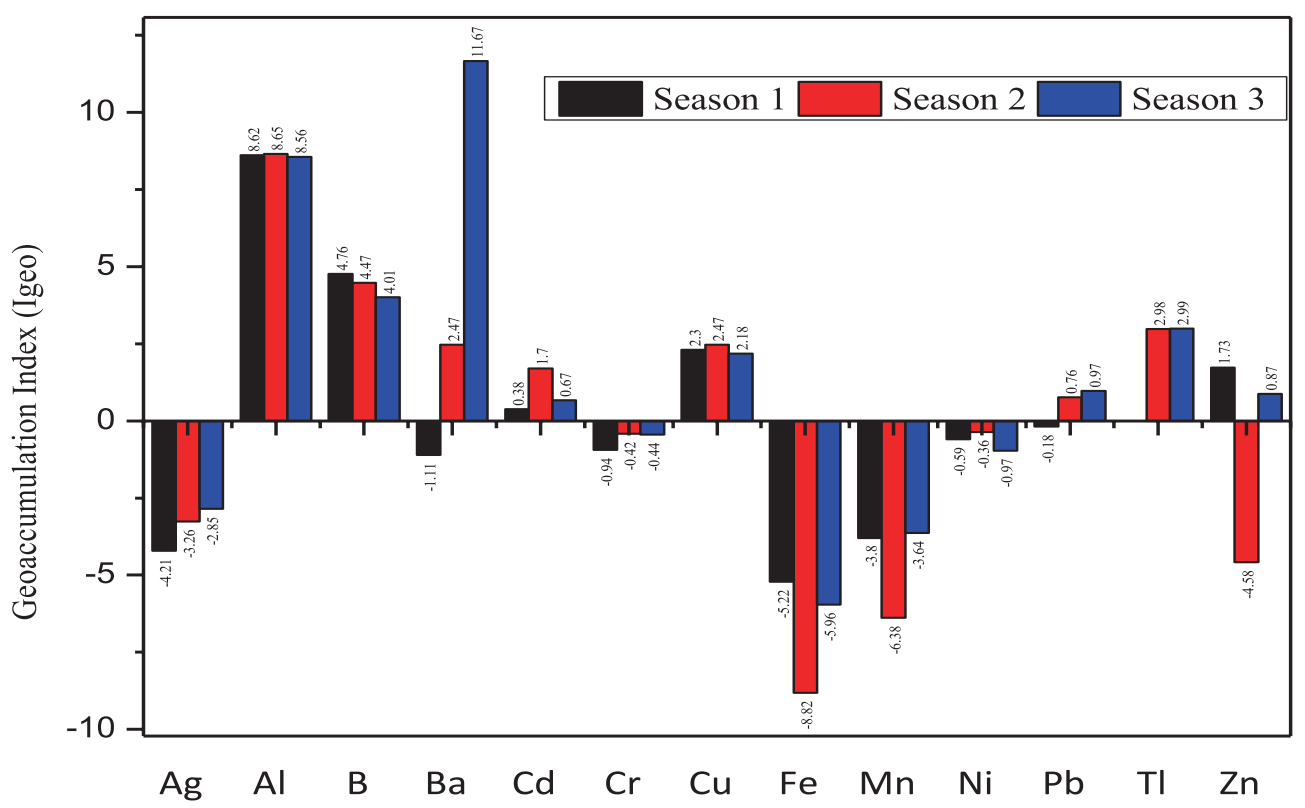

Fig. 6. Geo-accumulation index of different metals of $n=15$ sample in three seasons. 
of calculated values in the range of 0-6 having no contamination to very strong contamination in soil below which harmful effects are unlikely to be observed and above that severe toxicity may arise [38] (Table S4). The geo-accumulation index also reveals that samples are strongly contaminated by $\mathrm{Al}$ (Fig. 6). In addition to aluminum, other metals such as $\mathrm{Cd}, \mathrm{Cu}$, and $\mathrm{Pb}$ cause high contamination, whereas some are moderately contaminating, such as $\mathrm{Zn}$ and $\mathrm{Ni}$, and the remaining are non-contaminating on the basis of their accumulation in the soil, such as Ag, $\mathrm{Fe}, \mathrm{Mn}$, and $\mathrm{Ni}$. Mn is also one of the heavy metals that have shown toxicity in the environment. Another aspect of $\mathrm{Mn}$ is that it is not an element that produces soil contamination, because it is an important plant nutrient and an essential crop micronutrient. A similar research study was conducted to evaluate grain size characteristics, the seasonal and spatial variations of heavy metals ( $\mathrm{Mn}, \mathrm{Cr}, \mathrm{Ni}, \mathrm{Fe}, \mathrm{Pb}, \mathrm{Zn}, \mathrm{Fe}$ and $\mathrm{Cu}$ ) in Yangtze Estuary, China and the results obtained are in a close agreement with our results [39]. Table 3 depicts the numerical calculation of Igeo values in percentages for the classification of metals with respect to contamination. According to an overview of the values, they are classified as uncontaminated, moderately contaminated, or strongly contaminated. $\mathrm{Ag}, \mathrm{Fe}, \mathrm{Mn}$, and $\mathrm{Zn}$ fall into Class $1, \mathrm{Ba}, \mathrm{Cd}, \mathrm{Cr}, \mathrm{Cu}, \mathrm{Ni}, \mathrm{Pb}$, and $\mathrm{Tl}$ in Class 2, and $\mathrm{Al}$ in Class 3. In a similar study of the occurrence and distribution of metals in a municipal landfill waste in Guangzhou, China, it was found that $\mathrm{Cr}$ and $\mathrm{Pb}$ were dominant metals in soil contamination, with 2.82 and $4.50 \mathrm{mg}$ concentrations, respectively [40], and it was found that their concentration in soils was controlled by the particle size, as accumulation is inversely related to particle size. Finer particles as found in our study, due to their large surface area, adsorb more heavy metals, so particle size fractions on heavy metal concentrations are very important because the particles themselves are pollutants that influence particle transportability [41, 42]. A study on risk assessment of heavy metals $(\mathrm{Zn}, \mathrm{Mn}, \mathrm{Fe}, \mathrm{Cr}, \mathrm{Pb}, \mathrm{Cd}$, $\mathrm{Cu}$ ) in soils of Zhejiang province, China, indicated that there is a seasonal variation in geo accumulation index and enrichment factor concentrations of heavy metals. $\mathrm{Cd}$ and $\mathrm{Cr}$ showed random distribution in both (winter and summer) seasons. The values of mean concentration of heavy metals ranging from 5.09 to $10351.83 \mathrm{mg} / \mathrm{kg}$, were in close agreement with our results [43]. In another research study, the impact of seasonal water logging on selected metals ( $\mathrm{Ba}, \mathrm{Cr}, \mathrm{Ni}, \mathrm{As}, \mathrm{Pb}, \mathrm{Co}, \mathrm{Cs}$ ) and metal oxides $\left(\mathrm{Al}_{2} \mathrm{O}_{3}, \mathrm{Fe}_{2} \mathrm{O}_{3}\right)$ was investigated in the soil samples taken from the eastern Ganges basin. The average concentrations of these metals were higher in the seasonally waterlogged soil than the seasonally nonwaterlogged soil. Higher content of metals in the upper layers of soil was due to clay fractions and absorption of elements by the soil [44].

\section{Enrichment Factor}

The normalized enrichment factor (EF) is a wellestablished common approach to estimate the potential of metal concentrations above uncontaminated background levels in sediments. In the method of estimating the enrichment factor, the measured heavy metal concentration is normalized by the concentration of the sample's reference metal, such as Fe or Al [45]. Commonly, the concentration of reference metals such as $\mathrm{Fe}$ and $\mathrm{Al}$ are used as a "proxy" for the clay content [18-20]. In the present study, the enrichment factor was estimated for 12 determined metals, which were present in the sediment samples and presented as a range of three seasons, by keeping $\mathrm{Fe}$ as a reference (Table 4). Iron has a concentration that is high enough to contaminate the soils; hence, since it has the lowest toxicity relative to its occurrence in sediments, it was selected as a reference metal. The enrichment values of 12 metals calculated using Equation (2) revealed a significant potential for all three seasons. Aluminum showed a high level of enrichment in all three seasons, following tellurium in Season 2 and Season 3, and the remaining metals also showed enough enrichment to pollute the soil environment. Khalilova and Mammadov also calculated the maximum, minimum and mean values of

Table 3. Seasonal accumulation (\%) of metals in soil calculated from Igeo values.

\begin{tabular}{|c|c|c|c|c|c|c|c|c|c|c|c|c|c|c|}
\hline Seasons & Levels & $\mathrm{Ag}$ & $\mathrm{Al}$ & B & $\mathrm{Ba}$ & $\mathrm{Cd}$ & $\mathrm{Cr}$ & $\mathrm{Cu}$ & $\mathrm{Fe}$ & $\mathrm{Mn}$ & $\mathrm{Ni}$ & $\mathrm{Pb}$ & $\mathrm{Tl}$ & $\mathrm{Zn}$ \\
\hline \multirow{3}{*}{ Season 1} & Uncontaminated & 100 & 7 & - & 73 & 40 & 80 & 7 & 100 & 100 & 93 & 60 & - & 20 \\
\hline & Moderate & - & - & 13 & 20 & 60 & 20 & 67 & - & - & 7 & 27 & - & 47 \\
\hline & Strong & - & 93 & 87 & 7 & - & - & 27 & - & - & - & 13 & - & 33 \\
\hline \multirow{3}{*}{ Season 2} & Uncontaminated & 100 & - & - & - & 7 & 73 & - & 100 & 100 & 73 & 53 & - & 100 \\
\hline & Moderate & - & - & 20 & 67 & 67 & 27 & 67 & - & - & 27 & 27 & 53 & - \\
\hline & Strong & - & 100 & 80 & 33 & 27 & - & 33 & - & - & - & 20 & 47 & - \\
\hline \multirow{3}{*}{ Season 3} & Uncontaminated & 100 & - & - & 67 & 7 & 67 & 7 & 100 & 100 & 100 & 60 & - & 27 \\
\hline & Moderate & - & - & 20 & 33 & 93 & 27 & 67 & - & - & - & 20 & 53 & 60 \\
\hline & Strong & - & 100 & 80 & - & - & 7 & 27 & - & - & - & 20 & 47 & 13 \\
\hline
\end{tabular}


$\mathrm{EF}$ of $\mathrm{Cd}, \mathrm{Cr}, \mathrm{Cu}, \mathrm{Hg}, \mathrm{Pb}, \mathrm{Zn}$ and $\mathrm{Mn}$ in sediment and soil samples from different study sites, and these EF values are in close agreement with those reported in our study [38]. Overall, the enrichment level of heavy levels decreases in the order of $\mathrm{Cr}, \mathrm{Pb}>\mathrm{Zn}, \mathrm{Cu}>\mathrm{As}, \mathrm{Cd}>\mathrm{Hg}$. The increased levels of $\mathrm{Pb}$ are due to various industrial products and deposition of atmospheric emissions. In a similar research study, seasonal and spatial variations of heavy metals $(\mathrm{Zn}, \mathrm{Cu}, \mathrm{Cd}, \mathrm{Mn}, \mathrm{Ni}, \mathrm{Pb})$ were assessed in sediments of China's Tiaozi River. The results showed that the minimum concentrations of these heavy metals occurred in summer and the maximum in winter. Assessment of pollution concluded that the sediment was slightly contaminated with $\mathrm{Cd}, \mathrm{Cu}, \mathrm{Zn}$ and Ni. The concentrations of metals were in the order of $\mathrm{Mn}>\mathrm{Zn}>\mathrm{Cu}>\mathrm{Ni}>\mathrm{Pb}>\mathrm{Cd}[46,47]$.

Many researchers have calculated the normalized metal enrichment factor to obtain environmental sustainability control through heavy metals at different times and from different sources. Rolka et al. determined the contents of heavy metals in soil along Sielska Street in Olsztyn and described that the analysis of variance showed that significant changes have taken place with respect to $\mathrm{Cr}$ and Fe only [48]. Fe metal shows a relatively high natural abundance and is therefore not expected to be enriched from anthropogenic sources in sediments. In a similar research study enrichment in reference to $\mathrm{Al}$ and $\mathrm{Fe}$ to differentiate between natural and anthropogenic metal sources in Texas estuaries sediments also calculated [49]. In another research study, the content of heavy metals $(\mathrm{Pb}, \mathrm{Cd}, \mathrm{Mn}, \mathrm{Zn}, \mathrm{Fe}, \mathrm{Cu}$ and $\mathrm{Cr}$ ) in soil was determined and it was concluded that the concentrations of heavy metals did not exceed the respective international permissible limits [50]. All the studies have discuss criteria for calculating metal enrichment in sediments and soils and then followed in the present study and found significant enrichment of heavy metals in the soils. Brady et al. and Pandey et al. determined the enrichment factor values of lead (average EF 13) and zinc (average EF 2.7), which were in close agreement with our results [51, 52].

\section{Conclusions}

The present study aims to evaluate the occurrence, seasonal variations of various metals in waste sediment samples which is dumped by industries, accumulate and contaminate soils. A number of 15 different potential points of Gujranwala shown in map (Fig. 1) were chosen. The metal concentrations obtained after analysis in sediment samples of industrial waste were used to calculate environmental risks as geoaccumulation (Igeo) and enrichment factor. The analysis of samples of all three seasons showed variable concentrations of metals in three seasons showing significant seasonal variation of some heavy and toxic metals. Overall, the average concentration of $\mathrm{Al}, \mathrm{Cu}, \mathrm{B}$, 
$\mathrm{Cr}, \mathrm{Cd}, \mathrm{Tl}$ and $\mathrm{Zn}$ for all sample in three seasons were found higher than the average crustal value (ACV). The presence of higher concentrations of metals in waste samples than earth crust values is a clear indication metal pollution and their effect in the soil. Afterward, the various risk factors like geo-accumulation index (Igeo), and enrichment factor calculated to estimate the metal pollution in the urban soil because of industrial waste in urban sites. The result reveals that uncontrolled waste from metal industries have high level of heavy metals concentration which may cause soil pollution. It has made the understanding of the research team with certain understanding that a higher risk of environmental contamination of soil is present by the heavy metals added by the industries through unmanaged waste. It may be assumed on the findings that there is need of proper disposal criteria for the metal industrial waste. Law enforcement agencies of the country in general and Environmental Protection Agency (EPA) in specific should take serious action to regulate metal industrial waste through sustainable management. Samples analysis has revealed that a considerable amount of metals is present in the samples therefore, a sustainable and economical solution of converting the potential of metals in the waste into energy linked application is worth applicable. It may be advocated that preventive measures are necessary for the management of industrial waste enriched with heavy metals, to reduce the risk on environment for sustainable living. It is obvious that industrial waste is enriched in some metals, therefore for sustainable management, metallic waste may be converted into pooled metals electrodes for various applications.

\section{Acknowledgements}

Present research work was performed by an MS student of Department of Chemistry, UOG. Field sampling was carried out with the support of District Office of Environment Protection Agency, Gujranwala, Punjab Pakistan. ICP-OES facility was provided by Ittehad Chemical industries, Gujranwala, Pakistan. Mr. Shahid Kareem lecturer of geography in the Govt. College University Lahore supported our study through map development.

Funding: The authors would like to extend their sincere appreciation to the research supporting Project Number (RSP-2020/236), King Saud University, Riyadh, Saudi Arabia.

\section{Conflict of Interest}

The authors declare no conflict of interest

\section{References}

1. INOUE K. Heavy metal toxicity. J Clinic Toxicol S, 3, 2161, 2013
2. TÜRKMEN A., TÜRKMEN M. Seasonal and spatial variations of heavy metals in the spiny rock oyster, Spondylus spinosus, from coastal waters of Iskenderun Bay, Northern East Mediterranean Sea, Turkey. Bulletin of environmental contamination and toxicology, 75 (4), 716, 2005.

3. ASSAMOI B., LAWRYSHYN Y. The environmental comparison of landfilling vs. incineration of MSW accounting for waste diversion. Waste Management, 32 (5), 1019, 2012.

4. KRISHNA A., GOVIL P. Heavy metal contamination of soil around Pali industrial area, Rajasthan, India. Environmental Geology, 47 (1), 38, 2004.

5. DUZGOREN-AYDIN N., WONG C., AYDIN A., SONG Z., YOU M., LI X. Heavy metal contamination and distribution in the urban environment of Guangzhou, SE China. Environmental geochemistry and health, 28 (4), 375, 2006.

6. DOABI S.A., KARAMI M., AFYUNI, M. YEGANEH M., Pollution and health risk assessment of heavy metals in agricultural soil, atmospheric dust and major food crops in Kermanshah province, Iran. Ecotoxicology and environmental safety, 163, 153, 2018.

7. WUANA R.A., OKIEIMEN F.E. Heavy metals in contaminated soils: a review of sources, chemistry, risks and best available strategies for remediation. Isrn Ecology, 2011, 2011.

8. AL-KHASHMAN O.A., Heavy metal distribution in dust, street dust and soils from the work place in Karak Industrial Estate, Jordan. Atmospheric environment, 38 (39), 6803, 2004

9. REHMAN W., ZEB A., NOOR N., NAWAZ M. Heavy metal pollution assessment in various industries of Pakistan. Environmental Geology, 55 (2), 353, 2008.

10. MINALLAH M., GHAFFAR A., RAFIQUE M., MOHSIN M., Urban growth and socio-economic development in gujranwala, pakistan: a geographical analysis. Pakistan Journal of Science, 68 (2), 176, 2016.

11. NARAYANA T. Municipal solid waste management in India: From waste disposal to recovery of resources? Waste Management, 29 (3), 1163, 2009.

12. ALAM P., AHMADE K. Impact of solid waste on health and the environment. International Journal of Sustainable Development and Green Economics (IJSDGE), 2 (1), 165, 2013.

13. SALEEM M., IQBAL J., SHAH M.H Study of seasonal variations and risk assessment of selected metals in sediments from Mangla Lake, Pakistan. Journal of Geochemical Exploration, 125, 144, 2013.

14. IQBAL J., SHAH M.H. Occurrence, risk assessment, and source apportionment of heavy metals in surface sediments from Khanpur Lake, Pakistan. Journal of Analytical Science and Technology, 5 (1), 28, 2014.

15. LIDE D.R. CRC handbook of chemistry and physics. CRC press. 85, 2004.

16. ABRAHIM G.M., PARKER R.J. Assessment of heavy metal enrichment factors and the degree of contamination in marine sediments from Tamaki Estuary, Auckland, New Zealand. Environ Monit Assess, 136 (1-3), 227, 2008.

17. KOCH R., SALOMONS W., FÖRSTNER U. Metals in the Hydrocycle. Berlin - Heidelberg - New York - Tokyo: Springer Verlag, 1984, 349 S., 149 Abb., DM 98. -. Acta hydrochimica et hydrobiologica, 13 (2), 267, 1985.

18. JIANG J., WANG J., LIU S., LIN C., HE M., LIU X. Background, baseline, normalization, and contamination 
of heavy metals in the Liao River Watershed sediments of China. Journal of Asian Earth Sciences, 73, 87, 2013.

19. WINDOM H.L., SCHROPP S.J., CALDER F.D., RYAN J.D., SMITH JR R.G., BURNEY L.C., LEWIS F.G., RAWLINSON C.H. Natural trace metal concentrations in estuarine and coastal marine sediments of the southeastern United States. Environmental Science \& Technology, 23 (3), 314, 1989.

20. DIN Z.B. Use of aluminium to normalize heavy-metal data from estuarine and coastal sediments of Straits of Melaka. Marine Pollution Bulletin, 24 (10), 484, 1992.

21. ZHANG G., BAI J., ZHAO Q., JIA J., WEN X. Heavy metals pollution in soil profiles from seasonal-flooding riparian wetlands in a Chinese delta: Levels, distributions and toxic risks. Physics and Chemistry of the Earth, Parts A/B/C, 97, 54, 2017.

22. AHMAD A., ARIF M.S., YASMEEN T., RIAZ M., RIZWAN M., SHAHZAD S.M., ALI S., RIAZ M.A., SAROSH M. Seasonal variations of soil phosphorus and associated fertility indicators in wastewater-irrigated urban aridisol. Chemosphere, 239, 124725, 2020.

23. YANG K., ZHU Y., SHAN R., SHAO Y., TIAN C. Heavy metals in sludge during anaerobic sanitary landfill: Speciation transformation and phytotoxicity. Journal of environmental management, 189, 58, 2017.

24. TANG Q., BAO Y., HE X., ZHOU H., CAO Z., GAO P., ZHONG R., HU Y., ZHANG X. Sedimentation and associated trace metal enrichment in the riparian zone of the Three Gorges Reservoir, China. Science of the Total Environment, 479, 258, 2014.

25. ADAMCZYK-SZABELA D., MARKIEWICZ J., WOLF W.M. Heavy metal uptake by herbs. IV. Influence of soil $\mathrm{pH}$ on the content of heavy metals in Valeriana officinalis L. Water, Air, \& Soil Pollution, 226 (4), 106, 2015.

26. BRAVO S., AMORÓS J., PÉREZ-DE-LOS-REYES C., GARCÍA F., MORENO M., SÁNCHEZ-ORMEÑO M., HIGUERAS P. Influence of the soil $\mathrm{pH}$ in the uptake and bioaccumulation of heavy metals ( $\mathrm{Fe}, \mathrm{Zn}, \mathrm{Cu}, \mathrm{Pb}$ and $\mathrm{Mn}$ ) and other elements (Ca, K, Al, Sr and $\mathrm{Ba}$ ) in vine leaves, Castilla-La Mancha (Spain). Journal of Geochemical Exploration, 174, 79, 2017.

27. CHEN M., MA L.Q. Comparison of four USEPA digestion methods for trace metal analysis using certified and Florida soils. Journal of Environmental Quality, 27 (6), 1294, 1998

28. CEPA C.E.P.A. Canadian Soil Quality Guidelines for the Protection of Environmental and Human Health.

29. ENVIRONMENT C.C.O.M.O.T. Canadian Environmental Quality Guidelines. Canadian Council of Ministers of the Environment. 2, 2002.

30. PARTH V., MURTHY N. SAXENA P.R. Assessment of heavy metal contamination in soil around hazardous waste disposal sites in Hyderabad city (India): natural and anthropogenic implications. Journal of Environmental research and management, 2 (2), 027, 2011.

31. ALFARO M.R., MONTERO A., UGARTE O.M., DO NASCIMENTO C.W.A., DE AGUIAR ACCIOLY A.M., BIONDI C.M., DA SILVA Y.J.A.B. Background concentrations and reference values for heavy metals in soils of Cuba. Environmental monitoring and assessment, 187 (1), 4198, 2015.

32. SUANON F., SUN Q., YANG X., CHI Q., MULLA S.I., MAMA D., YU C.-P. Assessment of the occurrence, spatiotemporal variations and geoaccumulation of fiftytwo inorganic elements in sewage sludge: A sludge management revisit. Scientific Reports, 7 (1), 5698, 2017.
33. HUSSAIN QAISER M.S., AHMAD I., AHMAD S.R., AFZAL M., QAYYUM A. Assessing Heavy Metal Contamination in Oil and Gas Well Drilling Waste and Soil in Pakistan. Polish Journal of Environmental Studies, 28 (2), 785, 2019.

34. NOROUZI S., KHADEMI H., AYOUBI S., CANO A.F., ACOSTA J.A. Seasonal and spatial variations in dust deposition rate and concentrations of dust-borne heavy metals, a case study from Isfahan, central Iran. Atmospheric Pollution Research, 8 (4), 686, 2017.

35. PAL D., MAITI S.K. Seasonal variation of heavy metals in water, sediment, and highly consumed cultured fish (Labeo rohita and Labeo bata) and potential health risk assessment in aquaculture pond of the coal city, Dhanbad (India). Environmental Science and Pollution Research, 25 (13), 12464, 2018.

36. AMJAD A., RANDHAWA M.A., JAVED M.S., MUHAMMAD Z., ASHRAF M., AHMAD Z., MURTAZA S. Dietary intake assessment of pyrethroid residues from okra and eggplant grown in peri-urban areas of Punjab, Pakistan. Environmental Science and Pollution Research, 1, 2019.

37. WUNZANI D., DAUDA M., WYASU G., DAVID D. Assessments of physicochemical properties and heavy metals content in soils from selected solid waste dumpsites in kaduna metropolis, kaduna state, nigeria. Science World Journal, 15 (1), 76, 2020.

38. KHALILOV H., MAMMADOV V. Assessing the Anthropogenic Impact on Heavy Metal Pollution of Soils and Sediments in Urban Areas of Azerbaijan's Oil Industrial Region. Polish Journal of Environmental Studies, 25 (1), 159, 2016.

39. XUE-FENG H., YAN D., JIAN-WEI F., SHENG-QIONG F., XIAO-JIANG G., SHI-YUAN X. Spatial and seasonal variations of heavy metals in wetland soils of the tidal flats in the Yangtze Estuary, China: Environmental implications. Pedosphere, 23 (4), 511, 2013.

40. DENG M., KUO D.T.F., WU Q., ZHANG Y., LIU X., LIU S., HU X., MAI B., LIU Z., ZHANG H. Organophosphorus flame retardants and heavy metals in municipal landfill leachate treatment system in Guangzhou, China. Environ Pollut, 236, 137, 2018.

41. IZAH S.C., BASSEY S.E., OHIMAIN E.I. Geo-accumulation index, enrichment factor and quantification of contamination of heavy metals in soil receiving cassava mill effluents in a rural community in the Niger Delta region of Nigeria. Molecular Soil Biology, 8 (2), 7, 2017

42. WANG X.-S., QIN Y., CHEN Y.-K. Heavy meals in urban roadside soils, part 1: effect of particle size fractions on heavy metals partitioning. Environmental Geology, 50 (7), 1061, 2006.

43. HASHMI M.Z., YU C., SHEN H., DUAN D., SHEN C., LOU L., CHEN Y. Risk assessment of heavy metals pollution in agricultural soils of siling reservoir watershed in Zhejiang province, China. BioMed research international, 2013. 2013.

44. RAJMOHAN N., NAGARAJAN R., JAYAPRAKASH M., PRATHAPAR S. The impact of seasonal waterlogging on the depth-wise distribution of major and trace metals in the soils of the eastern Ganges basin. Catena, 189, 104510, 2020.

45. RAVICHANDRAN M., BASKARAN M., SANTSCHI P.H., BIANCHI T.S. History of trace metal pollution in Sabine-Neches estuary, Beaumont, Texas. Environmental science \& technology, 29 (6), 1495, 1995. 
46. DONG D., LIU X., GUO Z., HUA X., SU Y., LIANG D. Seasonal and Spatial Variations of Heavy Metal Pollution in Water and Sediments of China's Tiaozi River. Polish Journal of Environmental Studies, 24 (6), 2371, 2015.

47. ZAHRA A., HASHMI M.Z., MALIK R.N., AHMED Z. Enrichment and geo-accumulation of heavy metals and risk assessment of sediments of the Kurang Nallah feeding tributary of the Rawal Lake Reservoir, Pakistan. Science of the Total Environment, 470, 925, 2014.

48. ROLKA E., ŻOŁNOWSKI A.C., SADOWSKA M.M. Assessment of Heavy Metal Content in Soils Adjacent to the DK16-Route in Olsztyn (North-Eastern Poland). Polish Journal of Environmental Studies, 29 (6), 4303, 2020.

49. LUOMA S.N. Processes affecting metal concentrations in estuarine and coastal marine sediments. Heavy metals in the marine environment, 124, 1990.

50. RÓŻYŁO K., ANDRUSZCZAK S., KWIECIŃSKAPOPPE E., RÓŻYŁO R., KRASKA P. Effect of Three
Years` Application of Biogas Digestate and Mineral Waste to Soil on Phytochemical Quality of Rapeseed. Polish Journal of Environmental Studies, 28 (2), 833, 2019.

51. BRADY J.P., AYOKO G.A., MARTENS W.N., GOONETILLEKE A. Enrichment, distribution and sources of heavy metals in the sediments of Deception Bay, Queensland, Australia. Marine pollution bulletin, 81 (1), 248, 2014.

52. PANDEY P., SWATI P., HARSHITA M., SHRADDHA M.Y., TIWARI A. Nanoparticles accelerated in vitro biodegradation of LDPE: A review. Advances in Applied Science Research, 6 (4), 17, 2015.

53. GUPTA S., JENA V., MATIC N., KAPRALOVA V., SOLANKI J. Assessment of geo-accumulation index of heavy metal and source of contamination by multivariate factor analysis. International Journal of Hazardous Materials, 2 (2), 18, 2014.

54. RUDNICK R., GAO S. Composition of the continental crust. The crust, 3, 1, 2003. 


\section{Supplementary Material}

Table S1. Sample $(\mathrm{n}=15)$ IDs, Locations and Physical Characteristics (Colour,Texture).

\begin{tabular}{|c|c|c|c|c|}
\hline Samples \# & Sample ID & Colour & Texture & Sampling Site \\
\hline Sample-1 & SZ1 & Blackish Grey & Amorphous Powder & Sanat Zar Road 1 \\
\hline Sample-2 & SZ2 & Light Grey & Amorphous Powder & Sanat Zar Road 2 \\
\hline Sample-3 & KFS1 & Blackish Grey & Small Granular & Kousar Fan Street 1 \\
\hline Sample-4 & KFS2 & Blackish Grey & Small Granular & Kousar Fan Street 2 \\
\hline Sample-5 & KFS3 & Shiny Grey & Granular powder & Kousar Fan Street 3 \\
\hline Sample-6 & SR1 & Light Brown & Fine granular powder & Sialkot Road 1 \\
\hline Sample-7 & SR2 & Brown & Granular & Sialkot Road 2 \\
\hline Sample-8 & SR3 & Grey & Large granules & Sialkot Road 3 \\
\hline Sample-9 & SR4 & Blackish & Small Granular & Sialkot Road 4 \\
\hline Sample-10 & SR5 & Greyish Yellow & Granular & Sialkot Road 5 \\
\hline Sample-11 & AC1 & Blackish Grey & Fine Granular & Aalam Chowk 1 \\
\hline Sample-12 & AC2 & Grey & Amorphous Powder & Aalam Chowk 2 \\
\hline Sample-13 & CR1 & Black & Granular ash & Canal Road 1 \\
\hline Sample-14 & CR2 & Brown & Granular powder & Canal Road 2 \\
\hline Sample-15 & CR3 & Grey Black & Granular & Canal Road 3 \\
\hline
\end{tabular}

Table S2. Range of moisture (\%) of different samples $(\mathrm{n}=15)$ in three seasons.

\begin{tabular}{|c|c|c|c|c|}
\hline Sample & Range & Mean & Median & RSD $(\%)$ \\
\hline SZ1 & $1.50-3.11$ & 2.37 & 2.50 & 0.81 \\
\hline SZ2 & $0.60-5.00$ & 2.22 & 1.05 & 2.42 \\
\hline KFS1 & $9.70-14.70$ & 13.0 & 14.6 & 2.86 \\
\hline KFS2 & $0.20-0.50$ & 0.30 & 0.20 & 0.17 \\
\hline KFS3 & $0.90-5.00$ & 2.45 & 1.45 & 2.23 \\
\hline SR1 & $1.05-31.00$ & 11.5 & 2.50 & 16.87 \\
\hline SR2 & $0.15-27.90$ & 9.67 & 1.00 & 15.76 \\
\hline SR3 & $0.40-3.00$ & 1.54 & 1.21 & 1.33 \\
\hline SR4 & $2.30-9.60$ & 5.03 & 3.20 & 3.98 \\
\hline SR5 & $1.35-10.00$ & 4.52 & 1.35 & 4.77 \\
\hline $\mathrm{AC} 1$ & $15.00-35.20$ & 21.8 & 15.00 & 11.58 \\
\hline $\mathrm{AC} 2$ & $2.35-7.50$ & 4.79 & 2.35 & 2.58 \\
\hline CR1 & $1.20-17.70$ & 7.95 & 1.20 & 8.65 \\
\hline CR2 & $1.50-9.72$ & 4.82 & 1.50 & 4.33 \\
\hline CR3 & $1.50-3.62$ & 2.66 & 1.50 & 1.07 \\
\hline
\end{tabular}

RSD-Relative Standard Deviation 


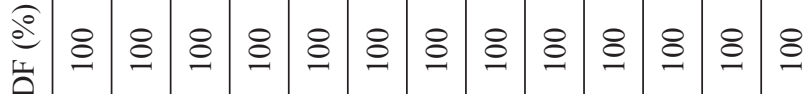

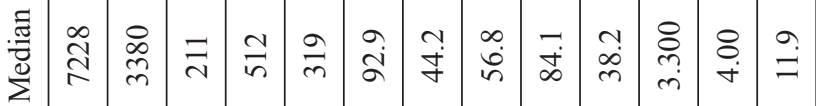

总

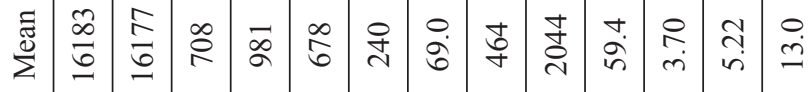

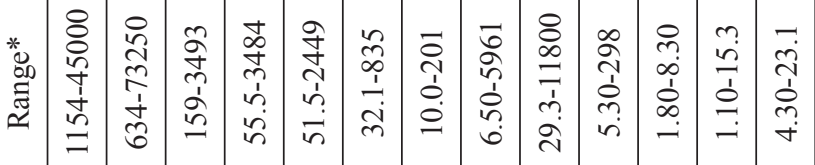

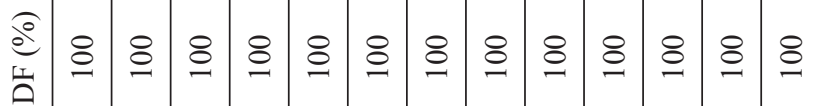

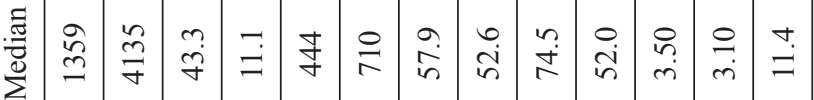

\begin{tabular}{l}
$\dot{m}$ \\
11 \\
0 \\
0 \\
0 \\
0 \\
0 \\
0 \\
0 \\
0 \\
0 \\
0 \\
0 \\
0 \\
0 \\
0 \\
\hline 11 \\
0
\end{tabular}

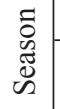

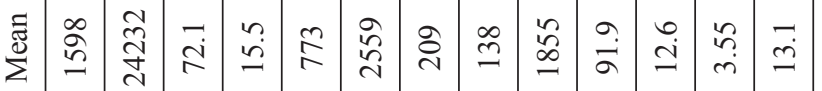

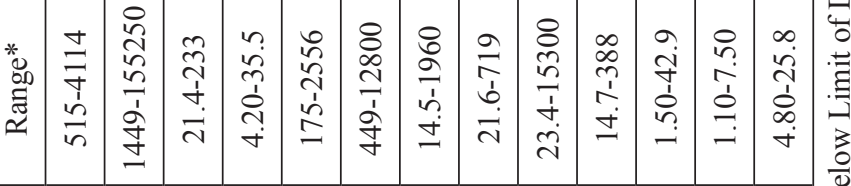

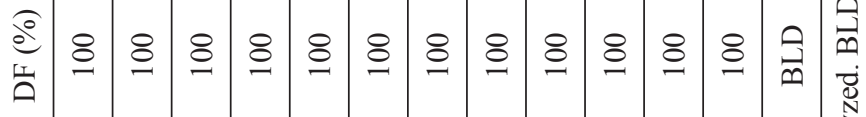

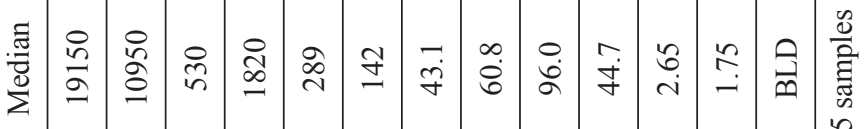

चี

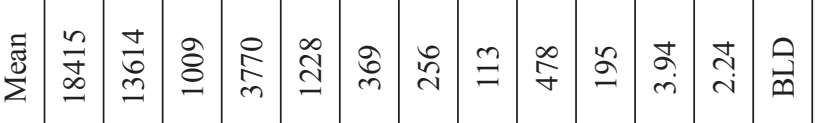

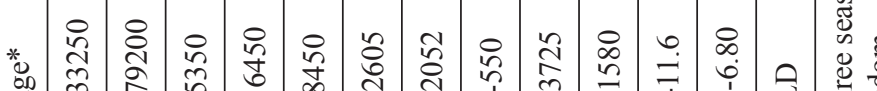

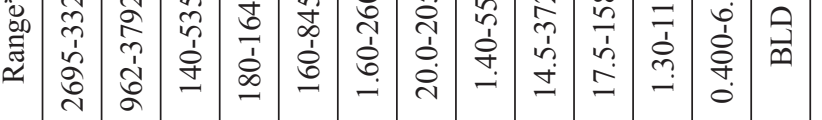
$\Xi$

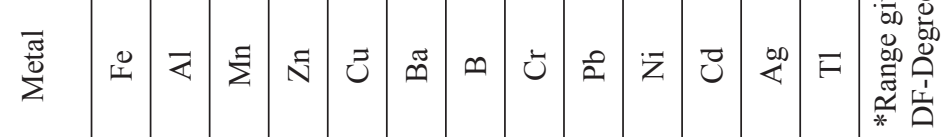


Table S4. Geo-accumulation index classification [53].

\begin{tabular}{|c|c|c|}
\hline Igeo & $\begin{array}{c}\text { Geo accumulation } \\
\text { intensity }\end{array}$ & Index, Igeo \\
\hline$>5$ & 6 & Very strong \\
\hline$>4-5$ & 5 & Strong to very strong \\
\hline$>3-4$ & 4 & Strong \\
\hline$>2-3$ & 3 & Moderate to strong \\
\hline$>1-2$ & 2 & Moderate \\
\hline$>0-1$ & 1 & Uncontaminated to moderate \\
\hline
\end{tabular}

Table S5. Bn the concentration of a given element in upper continental crust [54].

\begin{tabular}{|c|c|c|c|}
\hline Metal & $\begin{array}{c}\mathrm{Bn} \\
\left(\mathrm{mg} \mathrm{kg}^{-1}\right)^{*}\end{array}$ & Metal & $\begin{array}{c}\mathrm{Bn} \\
\left(\mathrm{mg} \mathrm{kg}^{-1}\right)^{*}\end{array}$ \\
\hline $\mathrm{Al}$ & $8.23 \mathrm{E}+04$ & $\mathrm{Sb}$ & $4.00 \mathrm{E}-01$ \\
\hline $\mathrm{Fe}$ & $5.63 \mathrm{E}+04$ & Hf & $5.30 \mathrm{E}+00$ \\
\hline $\mathrm{P}$ & $2.33 \mathrm{E}+04$ & $\operatorname{Re}$ & $1.98 \mathrm{E}-01$ \\
\hline $\mathrm{Ca}$ & $4.15 E+04$ & $\mathrm{Tl}$ & $9.00 \mathrm{E}-01$ \\
\hline $\mathrm{K}$ & $2.09 \mathrm{E}+04$ & $\mathrm{Pd}$ & $5.40 \mathrm{E}-04$ \\
\hline $\mathrm{Mg}$ & $1.05 \mathrm{E}+03$ & $\mathrm{Ag}$ & $5.30 \mathrm{E}-02$ \\
\hline $\mathrm{Na}$ & $2.36 \mathrm{E}+04$ & $\mathrm{Au}$ & $1.50 \mathrm{E}-03$ \\
\hline $\mathrm{Mn}$ & $9.50 \mathrm{E}+02$ & $\mathrm{Ru}$ & $3.40 \mathrm{E}-04$ \\
\hline W & $1.90 \mathrm{E}+00$ & $\mathrm{Ir}$ & $2.20 \mathrm{E}-05$ \\
\hline $\mathrm{Ti}$ & $5.70 \mathrm{E}+03$ & $\mathrm{Pt}$ & $5.00 \mathrm{E}-04$ \\
\hline $\mathrm{Ba}$ & $6.28 \mathrm{E}+02$ & $\mathrm{Ce}$ & $6.30 \mathrm{E}+01$ \\
\hline $\mathrm{Sr}$ & $3.20 \mathrm{E}+02$ & $\mathrm{Nd}$ & $2.70 \mathrm{E}+01$ \\
\hline $\mathrm{Zn}$ & $6.70 \mathrm{E}+01$ & $\mathrm{La}$ & $3.10 \mathrm{E}+01$ \\
\hline $\mathrm{Cu}$ & $2.80 \mathrm{E}+01$ & Y & $2.10 \mathrm{E}+01$ \\
\hline Sn & $2.10 \mathrm{E}+00$ & $\operatorname{Pr}$ & $7.10 \mathrm{E}+00$ \\
\hline $\mathrm{Ni}$ & $4.70 \mathrm{E}+01$ & $\mathrm{Sc}$ & $1.40 \mathrm{E}+01$ \\
\hline $\mathrm{Cr}$ & $9.20 \mathrm{E}+01$ & $\mathrm{Sm}$ & $4.70 \mathrm{E}+00$ \\
\hline $\mathrm{Ga}$ & $1.75 \mathrm{E}+01$ & $\mathrm{Gd}$ & $4.00 \mathrm{E}+00$ \\
\hline $\mathrm{Pb}$ & $1.70 \mathrm{E}+01$ & Dy & $3.90 \mathrm{E}+00$ \\
\hline V & $9.70 \mathrm{E}+01$ & $\mathrm{Er}$ & $2.30 \mathrm{E}+00$ \\
\hline $\mathrm{Co}$ & $1.73 \mathrm{E}+01$ & $\mathrm{Yb}$ & $1.96 \mathrm{E}+00$ \\
\hline As & $4.80 \mathrm{E}+00$ & $\mathrm{Eu}$ & $1.00 \mathrm{E}+00$ \\
\hline $\mathrm{Rb}$ & $8.40 \mathrm{E}+01$ & Ho & $8.30 \mathrm{E}-01$ \\
\hline $\mathrm{Nb}$ & $1.20 \mathrm{E}+01$ & $\mathrm{~Tb}$ & $7.00 \mathrm{E}-01$ \\
\hline Mo & $1.10 \mathrm{E}+00$ & $\mathrm{Tm}$ & $3.00 \mathrm{E}-01$ \\
\hline $\mathrm{Cd}$ & $9.00 \mathrm{E}-02$ & $\mathrm{Lu}$ & $5.00 \mathrm{E}-01$ \\
\hline
\end{tabular}

